\title{
"MANOBRA DA COMPRESSÃO DO SULCO CERVICAL COMO MEIO PROPEDEUTICO DE DIAGNOSTICO DE CIRCULAR CERVICAL DO CORDÃO UMBILICAL"
}

\author{
NOTA PREVIA
}

Toribia Mottos*

MOTTOS, T. Manobra da compressăo do sulco cervical como meio propedêutico de diagnóstico de circular cervical do cordão umbilical: nota prévia. Rev. Esc. Enf. USP, 11(3): 347-348, 1977.

$O$ presente trabalho pretende aquilatar a validade da manobra da compressão do sulco cervical, para estabelecer o diagnóstico de circular cervical do cordão umbilical.

Esse diagnóstico é deveras difícil de ser feito durante o trabalho de parto. Na maioria das vezes, só pode existir uma suposição de sua presença.

Do ponto de vista prático, na assistência à parturiente, é importante o diagnóstico de circular cervical pelas repercussões que esta patologia do funículo pode acarretar, entre elas o sofrimento fetal com o conseqüiente aumento de morbilidade e mortalidade peri-natais. Dessa forma, o profissional que assiste a parturiente pode prevenir a anóxia fetal grave.

* Professor Assistente da disciplina Enfermagem Obstétrica e Neonatal e Enfermagem Ginecológica da Escola de Enfermagem da Universidade de São Paulo. 
Nossos objetivos são: 1) verificar se a compressão do sulco cervical pode ser utilizada para o diagnóstico da circular cervical do cordão umbilical em primiparas e multiparas; 2) verificar se existe correlação entre a existência da circular do cordão umbilical e a vitalidade do recém-nascido.

O estudo piloto já foi realizado e estamos na fase de coleta de dados desta pesquisa.

MOTTOS, T. The process of the fetal neck curve compression as a manner for circle diagnosis: previous note. Rev. Esc. Enf. USP, 11(3): 347-348, 1977.

The author intends to examine the value of the process of the fetal neck compression to diagnose circle of the umbilical cord.

During labor the diagnosis of circles remains a supposition.

This pathologie may origin fetal distress, increasing perinatal morbidity and mortality.

The purposes of this work are:

- to examine if neck curve compression is valuable to diagnose circle of the umbilical cord in primipara und pluripara

- to examine if there is a correlation between the circle of the umbilical cord and the vitality of the newborn. 